\title{
Systemic doxycycline as an adjunct to scaling and root planing in diabetic patients with periodontitis: a systematic review and meta-analysis
}

\author{
Kenneth Chou Hung Yap and Shaju Jacob Pulikkotil ${ }^{*}$ (1)
}

\begin{abstract}
Background: To compare the effectiveness of systemic doxycycline as an adjunct to scaling and root planing (SRP) with SRP alone in improving periodontal clinical attachment level and glycemic control in diabetic patients with periodontitis.

Methods: Two independent reviewers (KY and SJ) screened two electronic databases, PubMed and Scopus, for randomized clinical trials on the use of systemic doxycycline as an adjunct to scaling and root planing in improving periodontal status and glycemic control in diabetic patients with periodontitis using predetermined selection criteria within a 3-month period. The reviewers independently did data screening, data selection, data extraction and risk of bias. Quality of studies involved was analysed using the revised Cochrane Risk of Bias 2.0. Weighted standard mean differences (SMD) and 95\% confidence intervals were calculated using a random effects metaanalysis model. Publication bias was evaluated using funnel plot. Quality of evidence was evaluated by Grading of Recommendations Assessment, Development and Evaluation (GRADE) approach.

Results: Electronic searches provided 1358 records and six studies were selected. The meta-analyses indicated that there was no statistically significant difference in the improvement of periodontal status with the use of systemic doxycycline as an adjunct for scaling and root planing (SRP). SMD of clinical attachment levels $(-0.22[-0.52,0.08])$ and HbA1c levels $(-0.13[-0.41,0.15])$ were calculated. Overall risk of bias is high in 2 out of 6 studies involved.

Conclusion: Systemic doxycycline when used in addition to scaling and root planing yields no significant improvement of clinical attachment levels for periodontal status and reduction of $\mathrm{HbA} 1 \mathrm{c}$ levels in treatment of diabetic patients with periodontitis when comparing the test group to the control group.
\end{abstract}

Keywords: Dental scaling, Diabetes, Doxycycline, Periodontitis, Root planing, Systematic review

\section{Background}

Periodontitis is a chronic inflammatory disease which leads to progressive destruction of the periodontium and tooth loss [1]. Removal and control of the accumulation of the plaque biofilm is the mainstay of periodontal treatment [2]. Scaling and root planing (SRP) is the mechanical removal of plaque, calculus and diseased cementum. Some patients might still encounter constant loss of attachment because of

* Correspondence: shajujacob@yahoo.com

School of Dentistry, International Medical University, 126, Jalan Jalil Perkasa 19, Bukit Jalil, Kuala Lumpur, Malaysia the failure of scaling and root planing to reduce or eliminate periodontal microorganisms to achieve health even after thorough SRP [3]. Some bacteria are likely to get away from host defenses after nonsurgical periodontal therapy due to restricted means of entry to the root surface and the tissue-invading abilities of the pathogens [4]. This raises the question of the effectiveness of SRP due to the bacteria residue in the tissues and also the inadequate plaque control of each patient [5]. To battle this phenomenon, a variety of antibiotics were used as adjunctive therapy to enhance the treatment outlook

(c) The Author(s). 2019 Open Access This article is distributed under the terms of the Creative Commons Attribution 4.0 International License (http://creativecommons.org/licenses/by/4.0/), which permits unrestricted use, distribution, and 
of SRP [6]. Systemic doxycycline have been long used as an adjunct to supplement the effect of scaling and root planing [7].

A substantially larger increase in CAL in diabetic patients with periodontitis who were given systemic doxycycline were seen as compared to without doxycycline after 3 months $[8,9]$. These outcomes shows that there is a better resolution of periodontal lesions when patients are given systemic doxycycline as compared to just SRP. On the contrary, other studies showed results that are contradictory to the previous results stating that there is no significant increase in CAL in the group that has received SRP with systemic doxycycline as compared to the group of patients treated with SRP after 3 months [10]. In terms of HbA1c levels, some studies suggested that there is a marked reduction in HbA1c levels in group with SRP with systemic doxycycline as compared to the control group which only had SRP. On the other hand, Promsudthi et al. and O'Connell et al. was not able to show a marked reduction in HbA1c levels when test group (SRP with doxycycline) and control group (SRP only) were compared to each other after 3 months $[9,10]$. There is a need to identify the efficacy of the systemic doxycycline in improving the periodontal health and glycemic control in diabetic patients with periodontitis given the lack of concrete evidence to show improved metabolic control and periodontal status when systemic doxycycline is used as an adjunct to scaling and root planing. This review based on a systematic search will identify the eligible studies and analyse data to determine the efficacy of systemic doxycycline as an adjunct to scaling and root planing in diabetic patients with periodontitis.

\section{Methods}

This review reported based on PRISMA guidelines and was registered in PROSPERO database (CDR42018103828). This is a systematic review of randomized clinical trials that evaluate differences in clinical attachment levels (CAL), pocket depth (PD), bleeding on probing (BOP) and glycated hemoglobin (HbA1c) levels in diabetic patients with periodontitis after scaling and root planing (SRP) with systemic doxycycline in comparison to just SRP alone.

\section{Research question according to PICOS}

What is the difference in the effect on the periodontal and glycemic status (O) with systemic doxycycline as an adjunct to scaling and root planing (SRP) (I) as compared to SRP alone (C) in diabetic patients with periodontitis (P) from randomized controlled trials $(\mathrm{S})$ ?

\section{Study selection}

Two electronic databases, Pubmed and Scopus, were searched using suitable keywords in various combinations until April 2018 to identify randomized controlled trails (RCTs) that compared systemic doxycycline as an adjunct to SRP (test group) to SRP alone (control group) in diabetic (type 1 or 2 ) patients with periodontitis.

\section{Inclusion criteria}

The subsequent inclusion criteria were used for the selection of studies:

(a) Randomized clinical trials;

(b) patients diagnosed with periodontitis and diabetes mellitus.

(c) interventions assessing the effectiveness of systemic doxycycline as an adjunct to SRP.

(d) studies reporting one or more clinical periodontal parameters as outcome including pocket depth (PD), or clinical attachment level (CAL)

(e) studies reporting metabolic parameter such as HbA1c before and after systemic doxycycline application and;

(f) studies published in English language only.

\section{Exclusion criteria}

The exclusion criteria included.

(a) in vitro and experimental studies.

(b) ex vivo studies.

(c) case reports.

(d) animal studies.

\section{Data extraction}

Titles and abstracts of articles that satisfy the selection protocol were screened independently by two reviewers (KY and SJ) with discord solved by discussion. Following selection of studies, data extraction was done on patient characteristics, disease characteristics, periodontal attachment outcome data in form of clinical attachment level (CAL), probing depth (PD), bleeding on probing (BOP) and glycemic status (HbA1c levels) with CAL and HbA1c levels being the primary outcome measurements for periodontal status and glycemic status respectively. Data extracted from the eligible studies were independently by two reviewers (KY and SJ) and disagreement resolved through discussion.

\section{Risk of bias assessment}

Risk of Bias assessment was done using the revised Cochrane tool 2.0 for Risk Of Bias (ROB) was done for all studies independently by two reviewers (KY and SJ) and consensus reached on disagreement. 


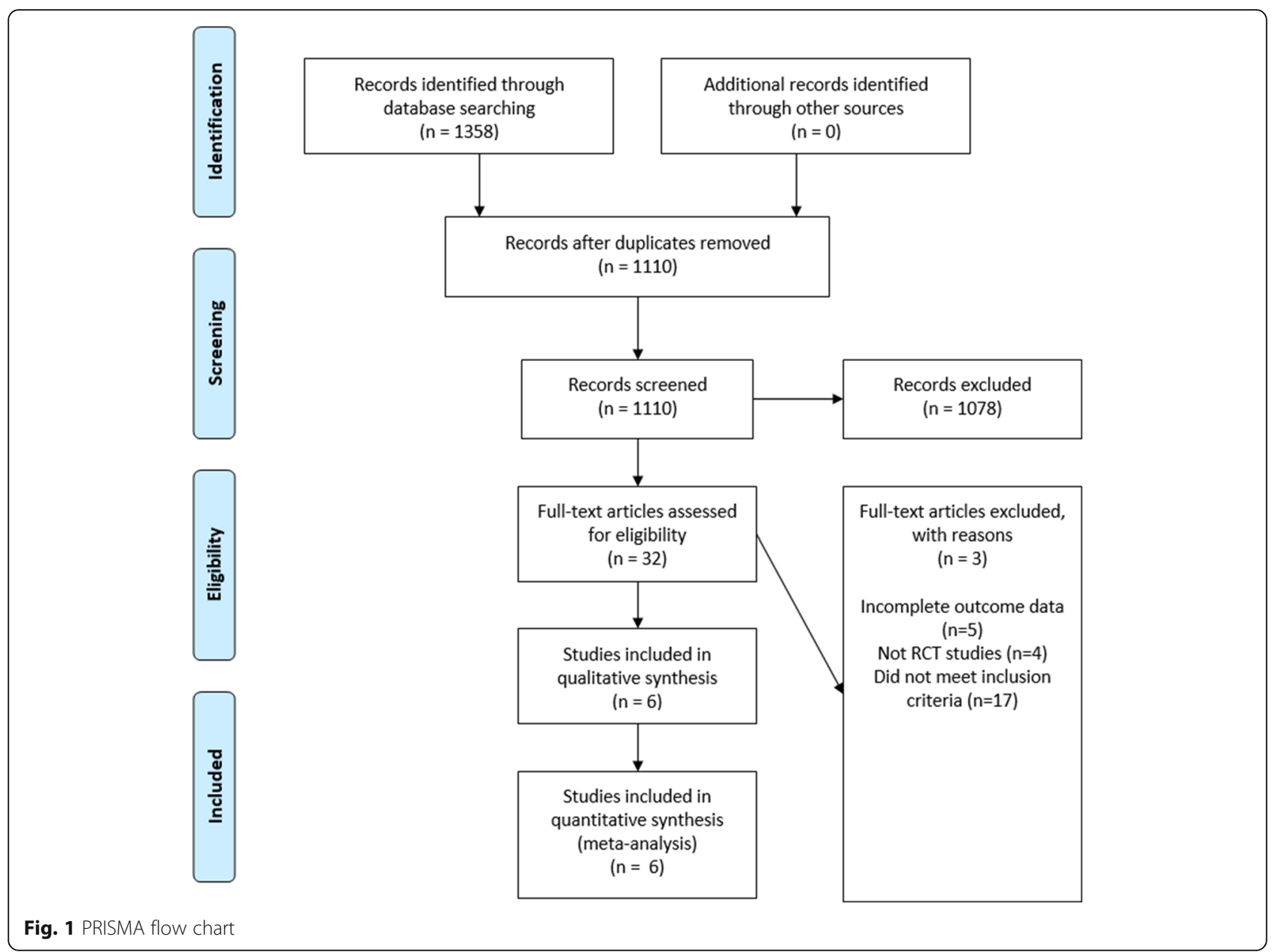

\section{Statistical analysis}

Meta-analysis was done using Review Manager 5.3. Primary meta-analysis using random effects model was done for eligible RCTs on CAL, PD, BOP and HbA1c levels. Subgroup analysis was done based on the patient characteristics identified from the studies. Sensitivity analysis based on risk of bias on the included studies. Publication bias was assessed through visualization of the funnel plot was done. Quality of evidence and confidence in estimates was assessed using GRADE Working Group criteria which was done using GRADE development tool using the method of assessing the certainty in evidence (also known as quality of evidence or confidence in effect estimates) and the strength of recommendations in health care.

\section{Results}

The electronic search retrieved 1358 records. No other additional records were identified through other sources. After removing the duplicates, there were 1110 records remaining, of which 1078 of them did not meet the inclusion criteria. After that, 32 of the remaining articles were assessed for eligibility. From these 32 studies, 26 of the studies did not meet the inclusion criteria and 6 of the studies were included

\begin{tabular}{|c|c|c|c|c|c|c|c|c|c|c|}
\hline \multirow[b]{2}{*}{ Study or Subgroup } & \multicolumn{3}{|c|}{ Systemic doxycycline } & \multicolumn{3}{|c|}{ SRP } & \multicolumn{2}{|c|}{ Std. Mean Difference } & \multirow{2}{*}{\multicolumn{2}{|c|}{$\begin{array}{c}\text { Std. Mean Difference } \\
\text { IV, Random, } 95 \% \mathrm{Cl}\end{array}$}} \\
\hline & Mean & SD & Total & Mean & SD & Total & Weight & IV, Random, 95\% Cl & & \\
\hline O'Connell 2008 & 8.9 & 4.8 & 15 & 14.2 & 12.5 & 15 & $49.0 \%$ & $-0.54[-1.28,0.19]$ & & \\
\hline Tsalikis 2014 & 12 & 16 & 15 & 12 & 12 & 15 & $51.0 \%$ & $0.00[-0.72,0.72]$ & & \\
\hline Total $(95 \% \mathrm{Cl})$ & & & 30 & & & 30 & $100.0 \%$ & $-0.27[-0.80,0.27]$ & & \\
\hline \multicolumn{6}{|c|}{$\begin{array}{l}\text { Heterogeneity: } \operatorname{Tau}^{2}=0.01 ; \mathrm{Chi}^{2}=1.09, \mathrm{df}=1(\mathrm{P}=0.30) ; \mathrm{I}^{2}=8 \% \\
\text { Test for overall effect: } Z=0.98(P=0.33)\end{array}$} & & & $\stackrel{\longmapsto}{-4}$ & 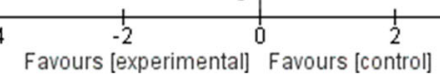 & 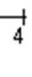 \\
\hline
\end{tabular}




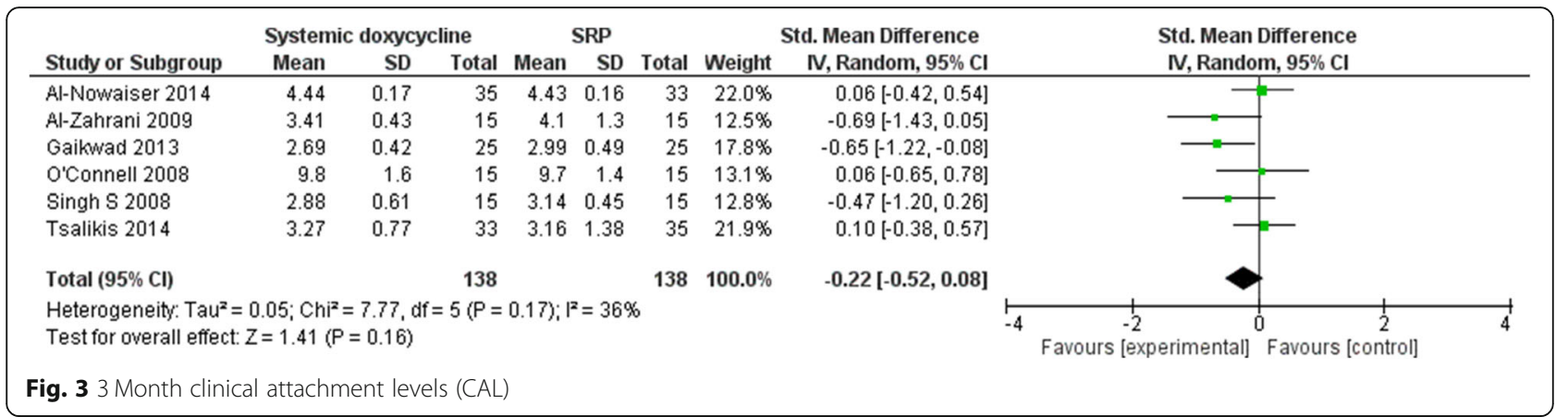

in the meta-analyses. Figure 1 shows the studies that have been found with duplicates removed, screened and assessed for eligibility. An in-depth analyses of all studies showed low-to-moderate heterogeneity [(BOP: $P=0.30, \quad \mathrm{I}_{2}=8 \% \quad$ (Fig. 2); CAL: $P=0.17, \quad \mathrm{I}_{2}=36 \%$ (Fig. 3); HbA1c: $P=0.39, \mathrm{I}_{2}=3 \%$ (Fig. 4); PD: $P=0.09$, $\mathrm{I}_{2}=48 \%$ (Fig. 5)]. All 6 studies had adequate data for the statistical analysis of CAL gain and $\mathrm{HbA1c}$ reduction at 3 months but insufficient data at 6 months and above. Total number of patients included are 276 at 3 months. Forest plots of primary and secondary data outcomes are given in Figs. 2, 3, 4 and 5. Metaanalysis showed no statistically significant improvement in CAL at 3 months (SMD -0.22; - 0.52, 0.08) and HbA1c levels at 3 months (SMD -0.13; - 0.41, $0.15)$ when systemic doxycycline is used as an adjunct to scaling and root planing compared to just SRP alone. It is the same case in PD (SMD -0.16;-0.50, 0.18 ) and BOP (SMD -0.27; $-0.80,0.27$ ) where there is no significant improvement when systemic doxycycline is used as an adjunct to scaling and root planing compared to just SRP alone after 3 months. This shows that there is no difference in effectiveness of systemic doxycycline as compared to control group.

Figure 6 provides information about the risk of bias of the studies that are included. From the tabled data, none of the 6 studies taken had a low risk of bias in any of the domains that were assessed. All 6 studies were reviewed by each of the reviewers independently and came up with the conclusion that only 2 out of 6 of the studies taken are at a high risk of bias, mainly Gaikwad 2013 and Al-Zahrani 2009.
Figure 7 shows GRADE Working Criteria which is used to assess the standard of the scientific research in systematic reviews [12]. Risk of bias of HbA1c levels and CAL data after 3 months was found to be serious due to the lack of information regarding allocation concealment in all 6 of the studies that were reviewed.

The general characteristics of all the 6 studies are shown in Table 1 . Some of the studies used different dose and duration of dose given to the patient.

\section{Discussion}

Results of 3-month Bleeding On Probing (BOP), Clinical Attachment Levels (CAL), Pocket depth (PD) and HbA1c levels are taken due to the limited number of studies done for 6 months and above for each of these clinical parameters. Systematic reviews like Grellmann AP et al. showed that the use of doxycycline did not significantly improve probing depths whereas Ronaldo Lira Junior et al. and Wang-Tze Fang et al. showed that adding doxycycline to periodontal therapy with SRP does not significantly improve metabolic control in patients with type 2 diabetes mellitus and chronic periodontitis [13-15]. Although systemic doxycycline inhibits metalloproteinase activity and also has antimicrobial effects which helps in reducing inflammation of periodontal tissues [15], HbA1c levels did not statistically improve after 3 months after administration of systemic doxycycline as an adjunct to SRP in our study. In terms of periodontal status, CAL, PD and BOP generally

\begin{tabular}{|c|c|c|c|c|c|c|c|c|c|c|c|}
\hline \multirow[b]{2}{*}{ Study or Subgroup } & \multicolumn{3}{|c|}{ Systemic doxycycline } & \multicolumn{3}{|c|}{ SRP } & \multicolumn{2}{|c|}{ Std. Mean Difference } & \multirow{2}{*}{\multicolumn{3}{|c|}{$\begin{array}{l}\text { Std. Mean Difference } \\
\text { IV, Random, } 95 \% \mathrm{Cl}\end{array}$}} \\
\hline & Mean & SD & Total & Mean & SD & Total & Weight & IV, Random, $95 \% \mathrm{Cl}$ & & & \\
\hline Al-Zahrani 2009 & 7.71 & 1.77 & 15 & 8.22 & 0.95 & 15 & $14.6 \%$ & $-0.35[-1.07,0.37]$ & $\because 1$ & F & \\
\hline Gaikwad 2013 & 7 & 0.76 & 25 & 7.11 & 0.99 & 25 & $24.3 \%$ & $-0.12[-0.68,0.43]$ & & - & \\
\hline O'Connell 2008 & 10.3 & 2.3 & 15 & 9.8 & 2 & 15 & $14.7 \%$ & $0.23[-0.49,0.94]$ & & & \\
\hline Singh 52008 & 7.5 & 0.6 & 15 & 7.3 & $0 . \overline{6}$ & 15 & $14.6 \%$ & $0.32[-0.40,1.05]$ & & & \\
\hline Tsalikis 2014 & 6.62 & 0.55 & 33 & 6.96 & 1.01 & 35 & $31.9 \%$ & $-0.41[-0.89,0.07]$ & & & \\
\hline Total $(95 \% \mathrm{Cl})$ & & & 103 & & & 105 & $100.0 \%$ & $-0.13[-0.41,0.15]$ & & & \\
\hline \multicolumn{6}{|c|}{$\begin{array}{l}\text { Heterogeneity: } \operatorname{Tau}^{2}=0.00 ; C h i^{2}=4.12, \mathrm{df}=4(\mathrm{P}=0.39) ; \mathrm{I}^{2}=3 \% \\
\text { Test for overall effect: } Z=0.92(P=0.36)\end{array}$} & & & & $\begin{array}{lcc}-4 & -2 & 1 \\
& \text { Favours [experimental] }\end{array}$ & \begin{tabular}{|cc} 
& 1 \\
0 & 2 \\
Favours [control]
\end{tabular} & $\frac{1}{4}$ \\
\hline
\end{tabular}




\begin{tabular}{|c|c|c|c|c|c|c|c|c|c|c|c|c|}
\hline \multirow[b]{2}{*}{ Study or Subgroup } & \multicolumn{3}{|c|}{ Systemic doxycycline } & \multicolumn{3}{|c|}{ SRP } & \multicolumn{2}{|c|}{ Std. Mean Difference } & \multirow{2}{*}{\multicolumn{4}{|c|}{$\begin{array}{c}\text { Std. Mean Difference } \\
\text { N, Random, } 95 \% \mathrm{Cl}\end{array}$}} \\
\hline & Mean & SD & Total & Mean & SD & Total & Weight & IV, Random, $95 \% \mathrm{Cl}$ & & & & \\
\hline Al-Nowaiser 2014 & 2.39 & 0.21 & 35 & 2.42 & 0.32 & 33 & $20.9 \%$ & $-0.11[-0.59,0.37]$ & & $\rightarrow$ & & \\
\hline Al-Zahrani 2009 & 2.82 & 0.23 & 15 & 2.64 & 0.7 & 15 & $13.6 \%$ & $0.34[-0.39,1.06]$ & & & & \\
\hline Gaikwad 2013 & 2.67 & 0.32 & 25 & 2.82 & 0.21 & 25 & $17.9 \%$ & $-0.55[-1.11,0.02]$ & & & & \\
\hline O'Connell 2008 & 1.9 & 0.3 & 15 & 2.1 & 0.3 & 15 & $13.3 \%$ & $-0.65[-1.39,0.09]$ & & & & \\
\hline Singh S 2008 & 2.14 & 0.46 & 15 & 2.33 & 0.35 & 15 & $13.5 \%$ & $-0.45[-1.18,0.27]$ & & & & \\
\hline Tsalikis 2014 & 2.46 & 0.52 & 33 & 2.29 & 0.56 & 35 & $20.8 \%$ & $0.31[-0.17,0.79]$ & & & & \\
\hline Total $(95 \% \mathrm{Cl})$ & & & 138 & & & 138 & $100.0 \%$ & $-0.16[-0.50,0.18]$ & & & & \\
\hline \multicolumn{9}{|c|}{$\begin{array}{l}\text { Heterogeneity: } \operatorname{Tau}^{2}=0.08 ; \mathrm{Chi}^{2}=9.60, \mathrm{df}=5(P=0.09) ; \mathrm{I}^{2}=48 \% \\
\text { Test for overall effect: } Z=0.91(P=0.36)\end{array}$} & -4 & $\begin{array}{cc}-2 & 0 \\
\text { Favours [experimental] }\end{array}$ & $\begin{array}{c}2 \\
\text { Favours [control] }\end{array}$ & 4 \\
\hline
\end{tabular}

showed no significant improvement when systemic doxycycline is used as an adjunct to SRP, although 1 study showed an a favorable increase in CAL when systemic doxycycline is used [16]. On the other hand, another study revealed a significant improvement in probing depths when systemic doxycycline is used as an adjunct to SRP [7]. This study that we have done also proves the current systematic reviews that systemic doxycycline as an adjunct to scaling and root planing (SRP) in diabetic patients with periodontitis does not show any benefit versus SRP alone in boosting metabolic control (HbA1c) as well as periodontal status in terms of clinical attachment levels (CAL) after 3 months of treatment.

The incorporation of doxycycline in SRP can have a higher chance to alter the pathogenic bacterial group, thus making it a more favorable environment for stable recolonization in the long run in gingival pockets which are recently scaled. This consequently creates a stable biofilm community which can also be found in individuals with no periodontal disease [17-19]. Nevertheless, bacterial resistance is an issue when there is broad usage of systemic antibiotics such as doxycycline used in periodontics [20]. Therefore, every clinician should weigh the pros and cons of prescribing these antibiotics to prevent bacterial resistance and other undesirable side effects of antibiotics. At this moment of time, about $75 \%$ of patients with chronic periodontitis showed that periodontal bacteria such as Aggregatibacter Actinomycetemcomitans are now resistant to at least one of the common antibiotics which includes doxycycline [21]. Thus, their prescription is only considered in clinical situations where the benefits of prescribing outweighs the undesired effects of antibiotics.

As shown in our study, there is no significant difference in CAL when systemic doxycycline is used as an adjunct to SRP and borderline statistical difference for PD. Although CAL is the gold standard for diagnosis of periodontitis, probing depths are also as important as CAL because the presence of deep pockets increases the risk of development of periodontal disease which will signals the need for more treatment [22, 23]. Studies from Sokransky and

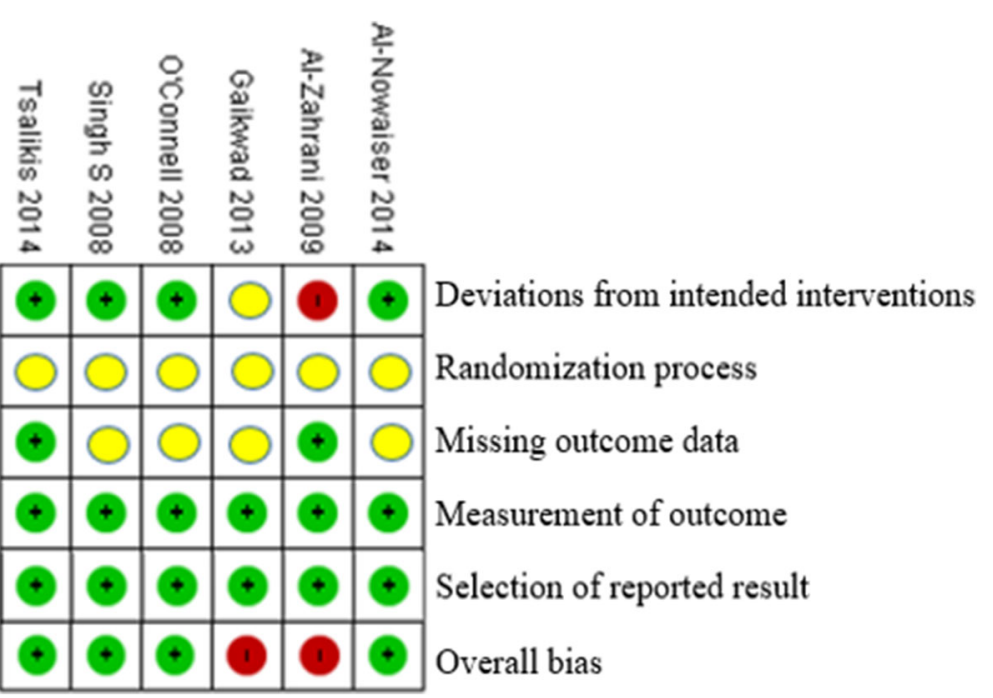

Fig. 6 Assessment of risk of bias. Green: low risk of bias, Yellow: Moderate risk of bias, Red: High risk of bias 


\begin{tabular}{|c|c|c|c|c|c|c|c|c|c|c|c|c|}
\hline \multicolumn{7}{|c|}{ Certainty assessment } & \multicolumn{2}{|c|}{ Ne of patients } & \multicolumn{2}{|c|}{ Effect } & \multirow{2}{*}{ Certainty } & \multirow{2}{*}{ Importance } \\
\hline $\begin{array}{l}\text { Ne of } \\
\text { studies }\end{array}$ & $\begin{array}{l}\text { Study } \\
\text { design }\end{array}$ & $\begin{array}{c}\text { Risk of } \\
\text { bias }\end{array}$ & Inconsistency & Indirectness & Imprecision & $\begin{array}{l}\text { Other } \\
\text { considerations }\end{array}$ & [intervention] & [comparison] & $\begin{array}{l}\text { Relative } \\
(95 \% \mathrm{Cl})\end{array}$ & $\begin{array}{l}\text { Absolute } \\
(95 \% \mathrm{CI})\end{array}$ & & \\
\hline \multicolumn{13}{|c|}{ HbA1c 3 months (follow up: 3 months) } \\
\hline 5 & $\begin{array}{l}\text { randomised } \\
\text { trials }\end{array}$ & serious a & not serious & not serious & not serious & none & 103 & 105 & - & $\begin{array}{c}\text { SMD } 0.13 \\
\text { SD lower } \\
(0.41 \\
\text { lower to } \\
0.15 \\
\text { higher) }\end{array}$ & $\underset{\text { MODERATE }}{\bigoplus \bigoplus \bigoplus \bigcirc}$ & CRITICAL \\
\hline \multicolumn{13}{|c|}{ CAL 3 months (follow up: 3 months) } \\
\hline 6 & $\begin{array}{c}\text { randomised } \\
\text { trials }\end{array}$ & serious $^{\text {a }}$ & not serious & not serious & not serious & none & 138 & 138 & - & \begin{tabular}{|c|} 
SMD 0.22 \\
SD lower \\
$(0.52$ \\
lower to \\
0.08 \\
higher $)$
\end{tabular} & $\underset{\text { MODERATE }}{\bigoplus \bigoplus \bigoplus \bigcirc}$ & CRITICAL \\
\hline
\end{tabular}

CI: Confidence interval; SMD: Standardised mean difference

\section{Explanations}

a. Allocation concealment is not stated in all 6 studies

Fig. 7 GRADE working criteria

Table 1 Characteristics table

\begin{tabular}{|c|c|c|c|c|c|c|c|c|c|}
\hline Study & Year & $\begin{array}{l}\text { Gender \& } \\
\text { number (n) }\end{array}$ & Country & $\begin{array}{l}\text { Number of } \\
\text { included } \\
\text { patients (n) }\end{array}$ & $\begin{array}{l}\text { Age range/ } \\
\text { mean (years) }\end{array}$ & $\begin{array}{l}\text { Periodontitis } \\
\text { type }\end{array}$ & Probing Method & Intervention & $\begin{array}{l}\text { Study } \\
\text { duration } \\
\text { (months) }\end{array}$ \\
\hline $\begin{array}{l}\text { Singh } \\
\text { et al. }\end{array}$ & 2008 & $\begin{array}{l}\text { Not } \\
\text { indicated }\end{array}$ & India & $\begin{array}{l}\text { Test (15) } \\
\text { Control (15) }\end{array}$ & $\begin{array}{l}\text { Not } \\
\text { indicated }\end{array}$ & $\begin{array}{l}\text { Moderate to } \\
\text { severe }\end{array}$ & $\begin{array}{l}\text { William's } \\
\text { periodontal probe, } \\
\text { sites not stated }\end{array}$ & $\begin{array}{l}\text { Test = Full mouth SRP }+ \\
\text { doxycycline } 100 \mathrm{mg}, 2 \text { tablets } \\
\text { taken on } 1^{\text {st }} \text { day, followed by } 1 \\
\text { tablet daily for } 14 \text { days } \\
\text { Control = Full mouth SRP }\end{array}$ & 3 \\
\hline $\begin{array}{l}\text { O'Connell } \\
\text { et al. }\end{array}$ & 2008 & $\begin{array}{l}\text { Female }-16 \\
\text { Male }-14\end{array}$ & Brazil & $\begin{array}{l}\text { Test (15) } \\
\text { Control (15) }\end{array}$ & 52.9 & Chronic & $\begin{array}{l}\text { Computerized } \\
\text { periodontal probe, } \\
6 \text { sites }\end{array}$ & $\begin{array}{l}\text { Test = Full mouth SRP }+ \\
\text { doxycycline } 100 \mathrm{mg}, 2 \text { tablets } \\
\text { taken on } 1^{\text {st }} \text { day, followed by } 1 \\
\text { tablet daily for } 14 \text { days } \\
\text { Control = Full mouth SRP }\end{array}$ & 3 \\
\hline $\begin{array}{l}\text { Al-Zahrani } \\
\text { et al. }\end{array}$ & 2009 & $\begin{array}{l}\text { Female }-18 \\
\text { Male }-11\end{array}$ & $\begin{array}{l}\text { Saudi } \\
\text { Arabia }\end{array}$ & $\begin{array}{l}\text { Test (15) } \\
\text { Control (14) }\end{array}$ & 52.28 & $\begin{array}{l}\text { Moderate to } \\
\text { severe } \\
\text { chronic }\end{array}$ & 6 sites & $\begin{array}{l}\text { Test }=\text { Full mouth SRP }+ \\
\text { doxycycline } 100 \mathrm{mg}, 2 \text { tablets } \\
\text { taken on } 1^{\text {st }} \text { day, followed by } 1 \\
\text { tablet daily for } 14 \text { days } \\
\text { Control = Full mouth SRP }\end{array}$ & 3 \\
\hline $\begin{array}{l}\text { Tsalikis et } \\
\text { al. }\end{array}$ & 2014 & $\begin{array}{l}\text { Female - } 28 \\
\text { Male - } 38\end{array}$ & Greece & $\begin{array}{l}\text { Test (31) } \\
\text { Control (35) }\end{array}$ & 60.42 & Chronic & $\begin{array}{l}\text { Automated Florida } \\
\text { probe, } 6 \text { sites }\end{array}$ & $\begin{array}{l}\text { Test }=\text { Full mouth SRP }+ \\
\text { doxycycline } 100 \mathrm{mg}, 2 \text { tablets } \\
\text { taken on } 1^{\text {st }} \text { day, followed by } 1 \\
\text { tablet daily for } 20 \text { days } \\
\text { Control = Full mouth SRP }\end{array}$ & 3,6 \\
\hline $\begin{array}{l}\text { Gaikwad } \\
\text { et al. }\end{array}$ & 2013 & $\begin{array}{l}\text { Female - } 16 \\
\text { Male - } 34\end{array}$ & India & $\begin{array}{l}\text { Test (25) } \\
\text { Control (25) }\end{array}$ & $30-70$ & $\begin{array}{l}\text { Chronic } \\
\text { generalized }\end{array}$ & $\begin{array}{l}\text { UNC } 15 \text { probe, } \\
4 \text { sites }\end{array}$ & $\begin{array}{l}\text { Test }=\text { Full mouth SRP }+ \\
\text { doxycycline } 100 \mathrm{mg} 1 \text { tablet } \\
\text { daily for } 15 \text { days } \\
\text { Control = Full mouth SRP }\end{array}$ & $1,2,3,4$ \\
\hline $\begin{array}{l}\text { Al- } \\
\text { Nowaiser } \\
\text { et al. }\end{array}$ & 2014 & $\begin{array}{l}\text { Female }-26 \\
\text { Male }-42\end{array}$ & $\begin{array}{l}\text { Saudi } \\
\text { Arabia }\end{array}$ & $\begin{array}{l}\text { Test (35) } \\
\text { Control (33) }\end{array}$ & 42 & Chronic & $\begin{array}{l}\text { manual Florida } \\
\text { periodontal probes, } \\
6 \text { sites }\end{array}$ & $\begin{array}{l}\text { Test = Full mouth SRP }+ \\
\text { doxycycline } 100 \mathrm{mg} 1 \text { tablet } \\
\text { daily for } 15 \text { days } \\
\text { Control = Full mouth SRP }\end{array}$ & 3 \\
\hline
\end{tabular}




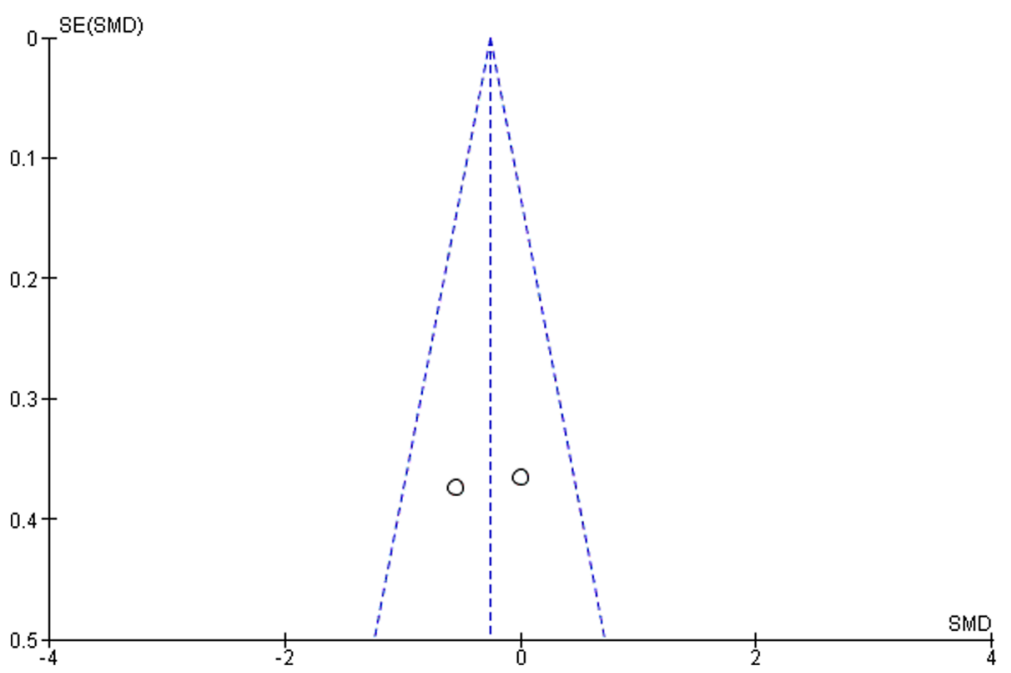

Fig. 83 Month bleeding on probing (BOP)

Haffajee et al. have demonstrated that more bacteria are found in deep pockets [17]. Increase in PD shows inflammatory changes, and clinical attachment levels will increase when inflammation of periodontium decreases and long junctional epithelium starts to develop [24].

Wang et al. have evaluated the efficacy of SRP with systemic doxycycline on reduction of $\mathrm{HbA1c}$ in diabetic patients in which 3 trials were included in the meta-analysis and there was no significant change in HbA1c levels by using systemic doxycycline as an adjunct to SRP [25]. As for Ronaldo Lira Junior et al's study, they had 3 extra trials and found results complementing Wang et al's study, proving that systemic doxycycline is not beneficial when used as an adjunct to SRP over SRP alone on in terms of reducing HbA1c levels [14]. These systematic reviews and meta-analyses are similar to our study which also shows that systemic doxycycline showed no significant benefits when used as an adjunct to SRP as compared to just SRP alone [$0.13(-0.41,0.15)]$.

In terms of heterogeneity of the studies involved, the hetereogeneity percentage for BOP, CAL, HbA1c and $\mathrm{PD}$ are $8,36,3$ and $48 \%$ respectively. According to Cochrane, $0-40 \%$ indicates low heterogeneity and $40-60 \%$ indicates moderate heterogeneity [29]. Results BOP and HbA1c are categorized as low heterogeneity, whereas CAL has a low to moderate heterogeneity. On the other hand, PD is categorized as moderate heterogeneity. The moderate heterogeneity of PD might be due to difference in dose and duration of systemic doxycycline as stated in the characteristics

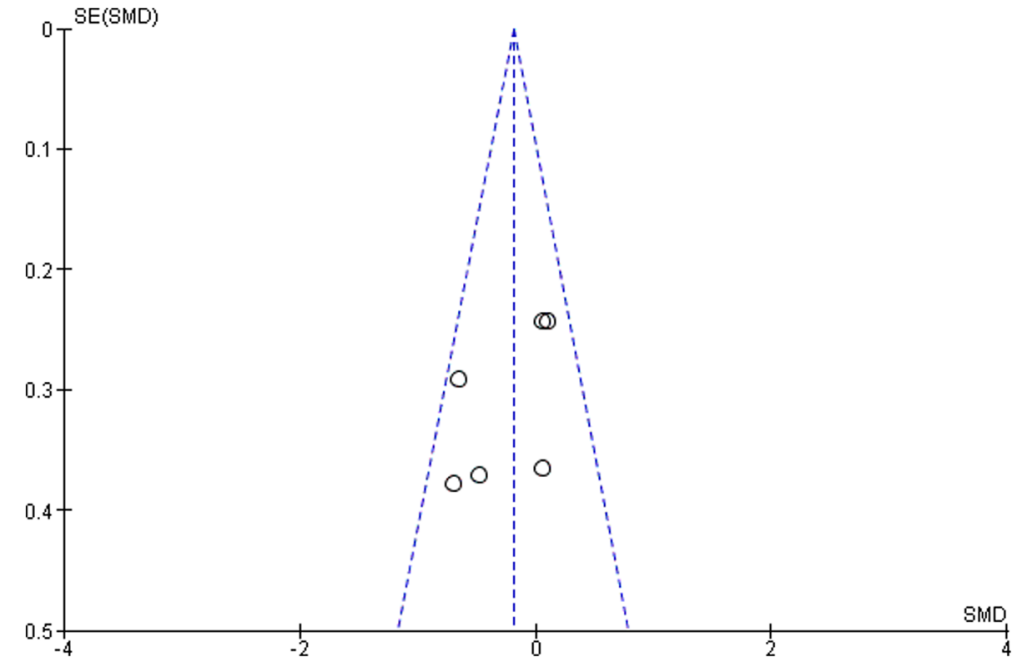

Fig. 93 Month clinical attachment levels (CAL) 


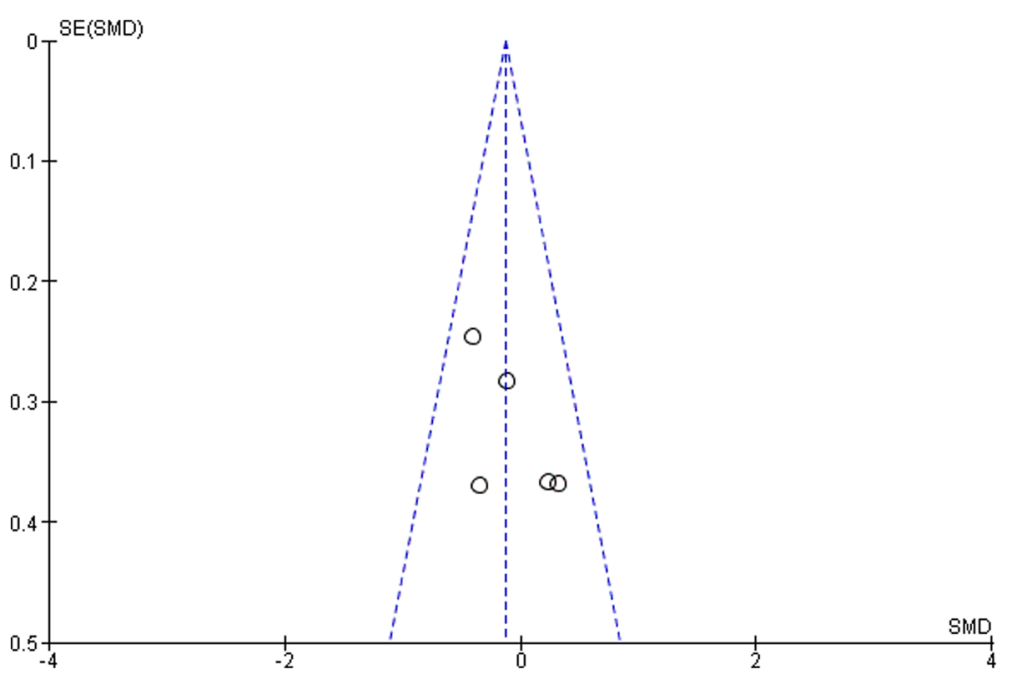

Fig. 103 Month glycated hemoglobin (HbA1c)

table in Table 1. However, since the primary outcomes are CAL and $\mathrm{HbA1c}$ which are calculated as low heterogeneity, it would not affect the results of the meta-analysis significantly.

From the GRADE assessment, certainty of the results of this meta-analysis is moderate which indicates that further research is will most probably have a major effect on our confidence intervals in the estimate of effect and may change the estimate. Certainty was moderate due to the moderate overall risk of bias in the 6 studies involved. The importance of this meta-analysis results is stated as "critical" because this systematic review aims to avoid the excessive use of systemic doxycycline without any tangible benefit, reducing the risk of antibiotic resistance against systemic doxycycline in the long run.
According to the funnel plots in Figs. 8, 9, 10 and 11, the studies involved are evenly distributed among the four funnel plots, suggesting that there was no publication bias. However, according to British Medical Journal (BMJ), tests for uneven distribution of studies in funnel plots are not used when there are 9 or less studies involved in any meta-analysis due to the low test power to differentiate substantial asymmetry from pure coincidence [26].

The main reason a meta-analysis is done is due to the fact that it has the superiority of having a better statistical power and its value as an evidence-based resource able to extrapolate confirmatory data analysis across the affected population. Nonetheless, the inadequate number of evidence in the present meta-analysis may not add to the current clinical

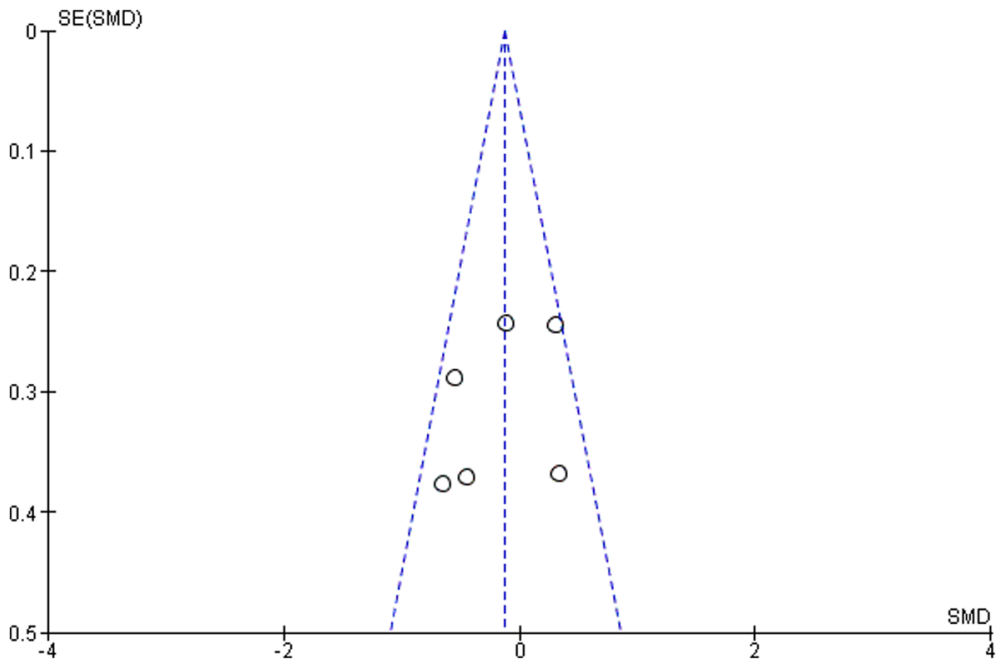

Fig. 113 Month pocket depth (PD) 
guidelines with confidence. The limitations of this systematic review includes a lack of timeframe which only includes a 3-month follow-up after systemic doxycycline is used $[7,10,11,16,27,28]$.

Besides that, another issue is the allocation concealment in which the risk of bias is fully unclear. No information was given on the allocation concealment, which affects the selection bias of all the six studies. Another concern is that the definition used in the present study lacked radiographic evidence of bone loss and were single-point in time measurements, although it would be a difficult task in epidemiological studies. Also, randomization of participants were not stated for three of the studies, namely Gaikwad et al., O'Connell et al. and Al-Nowaiser et al. [10, 16, 27], which might lead to selection bias. Strength of the reviews include prior protocol registration, subgroup and sensitivity done, grade shows the quality of evidence.

\section{Conclusion}

To sum up, systemic doxycycline as an adjunct to scaling and root planing does not significantly improve clinical attachment levels for periodontal status as well as reduction of $\mathrm{HbA1c}$ levels in treatment of diabetic patients with periodontitis. More randomized controlled trials with a larger population and longer follow-up periods are needed to come up with guidelines to treat diabetic patients with periodontitis in a more effective way than just scaling and root planing. Besides that, more work and planning needs to be done along with information given to reduce the risk of bias and prevent these methodologic shortcomings thus improving the quality of the trials done.

\section{Abbreviations}

BOP: Bleeding on probing; CAL: Clinical attachment levels; HbA1c: Glycated hemoglobin; PD: Pocket depth

\section{Acknowledgements}

This study was approved by the Ethics and Research Committee, International Medical University, Malaysia. The authors would like to thank Dr. Venkateshbabu Nagendrababu for his valuable assistance in this study.

\section{Authors' contributions}

KY and PSJ designed the study, gathered the information, performed the statistical analysis and manuscript writing. Both authors read and approved the final manuscript.

\section{Funding}

Publication of this article was funded by Ethics and Research Committee, International Medical University, Malaysia [BDS I-01/2018 (03)].

\section{Availability of data and materials}

The datasets used and/or analysed during the current study available from the corresponding author on reasonable request.

\section{Ethics approval and consent to participate}

Not applicable.

\section{Consent for publication}

Not applicable.

\section{Competing interests}

The authors declare that they have no competing interests.

Received: 6 April 2019 Accepted: 31 July 2019

Published online: 05 September 2019

\section{References}

1. Pei Shian T, Jacob Pulikkotil S. Comparison and agreement among various case definitions of periodontitis: a secondary data analysis. J Periodontol Implant Dent. 2014;6(2):40-6.

2. Becker W, Becker BE, Caffesse R, Kerry G, Ochsenbein C, Morrison E, et al. A longitudinal study comparing scaling, osseous surgery, and modified Widman procedures: results after 5 years. J Periodontol. 2001;72(12):1675-84.

3. Winkel EG, Van Winkelhoff AJ, Timmerman MF, Van der Velden U, Van der Weijden GA. Amoxicillin plus metronidazole in the treatment of adult periodontitis patients. A double-blind placebo-controlled study. J Clin Periodontol. 2001;28(4):296-305.

4. Ehmke B, Moter A, Beikler T, Milian E, Flemmig TF. Adjunctive antimicrobial therapy of periodontitis: long-term effects on disease progression and oral colonization. J Periodontol. 2005;76(5):749-59.

5. Caton JG, Ciancio SG, Blieden TM, Bradshaw M, Crout RJ, Hefti AF, et al. Treatment with subantimicrobial dose doxycycline improves the efficacy of scaling and root planing in patients with adult periodontitis. J Periodontol. 2000;71(4):521-32.

6. Hanes PJ, Purvis JP. Local anti-infective therapy: pharmacological agents. A systematic review. Ann Periodontol. 2003:8(1):79-98.

7. Tsalikis L, Sakellari D, Dagalis P, Boura P, Konstantinidis A. Effects of doxycycline on clinical, microbiological and immunological parameters in well-controlled diabetes type-2 patients with periodontal disease: a randomized, controlled clinical trial. J Clin Periodontol. 2014;41(10):972-80.

8. Grossi SG, Zambon JJ, Ho AW, Koch G, Dunford RG, Machtei EE, et al. Assessment of risk for periodontal disease. I. Risk indicators for attachment loss. J Periodontol. 1994;65(3):260-7.

9. Promsudthi A, Pimapansri S, Deerochanawong C, Kanchanavasita W. The effect of periodontal therapy on uncontrolled type 2 diabetes mellitus in older subjects. Oral Dis. 2005;11(5):293-8.

10. O'Connell PAA, Taba M, Nomizo A, Foss Freitas MC, Suaid FA, Uyemura SA, et al. Effects of periodontal therapy on glycemic control and inflammatory markers. J Periodontol. 2008;79(5):774-83.

11. Singh S, Kumar V, Kumar S, Subbappa A. The effect of periodontal therapy on the improvement of glycemic control in patients with type 2 diabetes mellitus: a randomized controlled clinical trial. Int J Diabetes Dev Ctries. 2008;28(2):38-44.

12. Dijkers, M. Introducing GRADE: a systematic approach to rating evidence in systematic reviews and to guideline development. KT Update (1)5. Austin: SEDL, Center on Knowledge Translation for Disability and Rehabilitation Research; 2013. p. 1-9.

13. Grellmann AP, Sfreddo CS, Maier J, Lenzi TL, Zanatta FB. Systemic antimicrobials adjuvant to periodontal therapy in diabetic subjects: a metaanalysis. J Clin Periodontol. 2016:43(3):250-60.

14. Lira Junior R, Santos C de MM, Oliveira BH, Fischer RG, Santos APP. Effects on $\mathrm{HbA1c}$ in diabetic patients of adjunctive use of systemic antibiotics in nonsurgical periodontal treatment: a systematic review. J Dent. 2017;66:1-7.

15. Wang T-F, Jen I-A, Chou C, Lei Y-P. Effects of periodontal therapy on metabolic control in patients with type 2 diabetes mellitus and periodontal disease: a meta-analysis. Medicine (Baltimore). 2014;93(28):e292.

16. Gaikwad SP, Gurav AN, Shete AR, Desarda HM. Effect of scaling and root planing combined with systemic doxycycline therapy on glycemic control in diabetes mellitus subjects with chronic generalized periodontitis: a clinical study. J Periodontal Implant Sci. 2013;43(2):79-86.

17. Socransky SS, Haffajee AD. Periodontal microbial ecology. Periodontol 2000. 2005;38:135-87.

18. Herrera $\mathrm{D}$, Alonso B, León R, Roldán $\mathrm{S}$, Sanz M. Antimicrobial therapy in periodontitis: the use of systemic antimicrobials against the subgingival biofilm. J Clin Periodontol. 2008;35(8 Suppl):45-66.

19. Feres M, Figueiredo LC, Soares GMS, Faveri M. Systemic antibiotics in the treatment of periodontitis. Periodontol. 2015;67(1):131-86.

20. van Winkelhoff AJ, Winkel EG. Microbiological diagnostics in periodontics: biological significance and clinical validity. Periodontol 2000. 2005;39:40-52.

21. Rams TE, Degener JE, van Winkelhoff AJ. Antibiotic resistance in human chronic periodontitis microbiota. J Periodontol. 2014;85(1):160-9.

22. Matuliene G, Pjetursson BE, Salvi GE, Schmidlin K, Brägger U, Zwahlen M, et al. Influence of residual pockets on progression of periodontitis and tooth 
loss: results after 11 years of maintenance. J Clin Periodontol. 2008;35(8): 685-95.

23. Matuliene G, Studer R, Lang NP, Schmidlin K, Pjetursson BE, Salvi GE, et al. Significance of periodontal risk assessment in the recurrence of periodontitis and tooth loss. J Clin Periodontol. 2010;37(2):191-9.

24. Polimeni G, Xiropaidis AV, Wikesjö UME. Biology and principles of periodontal wound healing/regeneration. Periodontol 2000. 2006;41:30-47.

25. Wang X, Han X, Guo X, Luo X, Wang D. The effect of periodontal treatment on hemoglobin a1c levels of diabetic patients: a systematic review and meta-analysis. PLoS One. 2014;9(9):e108412.

26. Sterne JAC, Sutton AJ, loannidis JPA, Terrin N, Jones DR, Lau J, et al. Recommendations for examining and interpreting funnel plot asymmetry in meta-analyses of randomised controlled trials. BMJ. 2011;343:d4002.

27. Al-Nowaiser AM, Al-Zoman H, Baskaradoss JK, Robert AA, Al-Zoman KH, Al-Sohail AM, et al. Evaluation of adjunctive systemic doxycycline with non-surgical periodontal therapy within type 2 diabetic patients. Saudi Med J. 2014;35(10):1203-9.

28. Al-Zahrani MS, Bamshmous SO, Alhassani AA, Al-Sherbini MM. Short-term effects of photodynamic therapy on periodontal status and glycemic control of patients with diabetes. J Periodontol. 2009;80(10):1568-73.

29. Ryan R. Cochrane Consumers and Communication Review Group. 'Heterogeneity and subgroup analyses in Cochrane Consumers and Communication Group reviews: planning the analysis at protocol stage. 2016. http://cccrg.cochrane.org. Accessed 11 Mar 2019.

\section{Publisher's Note}

Springer Nature remains neutral with regard to jurisdictional claims in published maps and institutional affiliations.

Ready to submit your research? Choose BMC and benefit from:

- fast, convenient online submission

- thorough peer review by experienced researchers in your field

- rapid publication on acceptance

- support for research data, including large and complex data types

- gold Open Access which fosters wider collaboration and increased citations

- maximum visibility for your research: over $100 \mathrm{M}$ website views per year

At $\mathrm{BMC}$, research is always in progress.

Learn more biomedcentral.com/submissions 